\title{
Characterization of Somatomedin/Insulin-like Growth Factor Receptors and Correlation with Biologic Action in Cultured Neonatal Rat Astroglial Cells
}

\author{
Victor K. M. Han, ${ }^{1}$ Jean M. Lauder, ${ }^{2}$ and A. Joseph D'Ercole ${ }^{1}$ \\ Departments of 'Pediatrics and 'Anatomy, School of Medicine, University of North Carolina at Chapel Hill, Chapel Hill, \\ North Carolina 27514
}

The role of somatomedin/insulin-like growth factors (Sm/ IGFs) in neural growth and development is not clearly defined. To characterize Sm/IGF receptors and to correlate binding with the biologic actions of Sm/IGFs in a homogeneous population of neural cells, we isolated and studied a nearly pure population of cultured astroglial monolayers derived from cerebral cortices of neonatal rats. Binding of radiolabeled Sm/IGFs was specific, saturable, and reversible, with $90 \%$ of the binding occurring within $6 \mathrm{hr}$ of incubation at $4^{\circ} \mathrm{C}$. Competitive binding studies with Sm-C/IGF I yielded curvilinear Scatchard plots, while studies with IGF II and multiplication stimulating activity (MSA) yielded linear plots, suggesting that ${ }^{25}$ I-Sm-C/IGF I binds to more than 1 receptor species, and ${ }^{125|-| G F ~|| ~ a n d ~}{ }^{125} \mid-$ MSA bind to one only. These findings were supported by affinity-labeling studies with radiolabeled $\mathrm{Sm} / \mathrm{IGFs}$ using disuccinimidyl suberate as a cross-linking agent. Sm-C/IGF I appeared to bind to both type I and II Sm/IGF receptors, because cross-linked 125|Sm-C/IGF I-receptor complexes with molecular weight $\left(M_{r}\right)$ of $>300,000$ (300K) and $130 \mathrm{~K}$ (type I receptor) were observed under nonreducing and reducing conditions, respectively, as were 220 and $260 \mathrm{~K}$ complexes (type II receptor) under the same respective conditions. ${ }^{25}$ |-IGF || and 125|MSA, however, bound only to the $M, 220$ and $260 \mathrm{~K}$ moieties under nonreducing and reducing conditions, respectively, suggesting that these peptides bind only to the type II receptor. Competitive binding studies of the cross-linked moieties were consistent with this interpretation. In contrast, ${ }^{125}$-insulin bound poorly to astroglla $(<0.5 \%$ specific binding), and cross-linking studies could not definitely distinguish among low-affinity binding to the type I Sm/lGF receptor, binding to a paucity of insulin receptors, or both. In addition, by combining autoradiography to localize ${ }^{125} \mid-\mathrm{Sm} /$ IGFs binding on astroglial cells and immunocytochemistry with anti-glial fibrillary acidic protein to identify the cell type,

\footnotetext{
Received Mar. 10, 1986; revised June 2, 1986; accepted June 24, 1986.

We wish to express our thanks to Judson Van Wyk, Marjorie Svoboda, and Peter Nissley for the generous supply of pure peptides, to Ken McCarthy for his help in purification of astroglial cells, to Debbie Bell for the technical assistance, and to Mrs. Sherry Handfinger for secretarial assistance. V.K.M.H. is a recipient of a Research Fellowship of the Medical Research Council of Canada. A.J.D. and J.M.L. are recipients of Research Career Development Awards HD00435 and NS00507 from the U.S. Public Health Service. This work was supported by the USPHS Grants HD08299 to A.J.D. and NS15706 to J.M.L.

Correspondence should be addressed to Victor K. M. Han, M.D., Department of Pediatrics, Division of Pediatric Endocrinology, Clinical Sciences Building $229 \mathrm{H}$, University of North Carolina, Chapel Hill, NC 27514.

Copyright (C) 1987 Society for Neuroscience $0270-6474 / 87 / 020501-11 \$ 02.00 / 0$
}

we have demonstrated cell-surface binding and apparent internalization of radiolabeled Sm/IGFs. Concurrent studies of $\mathrm{Sm} / \mathrm{IGF}$ stimulation of ${ }^{3} \mathrm{H}$-thymidine incorporation revealed that these cells were most sensitive to Sm-C/IGF I, followed by IGF II and MSA, and insulin. MSA and IGF II, however, were the most potent followed by Sm-C/IGF I and then insulin. Half-maximal stimulations of ${ }^{3} \mathrm{H}$-thymidine incorporation corresponded closely with half-maximal binding displacement for Sm-C/IGF I and less so for IGF II and MSA. These findings suggest that the mitogenic action of $\mathrm{Sm}$ / IGFs is mediated by Sm/IGF receptors and that both receptor types may be responsible for this effect. Our findings strongly support a biologic role for Sm/IGFs in the growth of developing astroglial cells that is mediated by specific receptors.

Somatomedins or insulin-like growth factors (Sm/IGFs) are polypeptide mitogens with amino acid sequences homologous to the A and B portions of proinsulin (for reviews, see Van Wyk, 1984, and Zapf et al., 1984). Two forms of Sm/IGFs have been purified from human plasma: somatomedin-C or insulin-like growth factor I (Sm-C/IGF I) (Humbel, 1983; Klapper et al., 1983), a basic peptide that is growth hormone dependent and generally helieved to mediate the growth-promoting properties of the latter, and insulin-like growth factor II (IGF II), a neutral peptide that is less growth hormone dependent (Rinderknecht and Humbel, 1978). In rats, homologs of Sm-C/IGF I (Rubin et al., 1982) and IGF II [also known as multiplication stimulating activity (MSA)] (Dulak and Temin, 1973; Moses et al., 1980; Marquardt et al., 1981) have been identified.

The role of Sm-C/IGF I in postnatal growth is well established and both $\mathrm{Sm} / \mathrm{IGFs}$ have been postulated to have a role in embryonic and fetal growth (Underwood and D'Ercole, 1984). A role for Sm/IGFs in growth and development of neural tissues has also been suggested. Sara et al. (1981) postulated that a form of somatomedin (termed human embryonic somatomedin) stimulates growth of human fetal brain cells in vitro and showed that both fetal and adult human brain tissue contains receptors to Sm/IGFs (Sara et al., 1982, 1983). Synthesis of Sm/IGFs by cultured brain cells has been demonstrated (Binoux et al., 1981; Birch et al., 1984) and cultured neural tissues can respond to Sm/IGFs (Westermark and Wasteson, 1975; Lenoir and Honegger, 1983; McMorris et al., 1986). More recent studies have shown that IGF II can be detected in human cerebrospinal fluid (Haselbacher and Humbel, 1982) and brain tissues (Haselbacher et al., 1985). In addition, very high levels of IGF II have been 
found in the brain of a newborn with megaencephaly (Schoenle et al., 1985).

In order to study the role of Sm/IGFs in the growth of a homogeneous population of defined neural cells, we have utilized techniques to separate neuronal and glial elements, and have performed detailed studies of Sm/IGF receptors and biologic actions in a homogeneous population of polygonal astroglial cells cultured and "purified" from neonatal rat cerebral cortices. Our findings demonstrate that these cells possess highaffinity receptors for both $\mathrm{Sm}$-C/IGF I (type I Sm/IGF receptor) and IGF II (type II Sm/IGF receptor) and suggest that each receptor can mediate a mitogenic response to these growth factors.

\section{Materials and Methods}

Materials. Sm-C/IGF I was purified as previously described from Cohn fraction IV of human plasma (Svoboda et al., 1980). IGF II was isolated by isoelectric focusing and high-performance liquid chromatography (Svoboda and Van Wyk, 1985), and was judged pure on the basis of a single band on SDS-PAGE and lack of ambiguity in the sequence analysis of the first 4 amino acids at the $\mathrm{NH}_{2}$ terminal end of the molecule (M. E. Svoboda, unpublished results). MSA III-2 was a gift of S. Peter Nissley, NCI, and monocomponent insulin was a gift from Dr. M. Root of E. Lilly Co. (Indianapolis, IN). The peptides were iodinated with $\mathrm{Na}^{125} \mathrm{I}$ (New England Nuclear, Boston, MA) according to a modification of the chloramine-T method (Furlanetto et al., 1977) to a specific activity of $150-200 \mu \mathrm{Ci} / \mu \mathrm{g}$. The iodinated Sm-C/IGF I was further purified by immunoaffinity chromatography and the other iodinated peptides by gel filtration on Sephadex G-50 in 1 м acetic acid as previously described (Van Wyk et al., 1980). The iodinated peptides were stored in $1 \mathrm{M}$ acetic acid and $3 \%$ BSA at $-70^{\circ} \mathrm{C}$ and uscd for the binding studics within 2 weeks after iodination. Unlabeled Sm-C/IGF I of at least $90 \%$ purity was used in the competition studies, while less pure preparations were used to determine nonspecific binding.

Astroglial cultures. A pure population of polygonal, flat astroglial cells were cultured from neonatal rat cerebral cortices as described by McCarthy and de Vellis (1980). Briefly, 1-d-old Sprague-Dawley rats (Charles River Breeding Laboratories, Wilmington, MA) were decapitated and the brains removed aseptically. The cerebral cortices were dissected and the meningeal coverings carefully peeled off. The cortical tissue was cut into small pieces and incubated in $0.1 \%$ trypsin and $0.02 \%$ EDTA solution (GIBCO Laboratories, Grand Island, NY) at room temperature for $30 \mathrm{~min}$ with constant shaking. Trypsin activity was inhibited by addition of twice the volume of Basal Medium Eagle (BME; GIBCO Laboratorics) containing $10 \%$ fetal calf serum (FCS; Hyclone, Sterile Systems Inc., Logan, UT). The cell suspension was removed and filtered through a $130 \mu \mathrm{M}$ nitex monofilament screen (Tetko, Elmsford, NY). The remaining tissues were triturated mechanically and filtered; the filtrate was combined with the initial cell suspension and was centrifuged at $2000 \times \mathrm{g}$. The cell pellet was gently vortexed and resuspended in complete medium (BME with $10 \%$ FCS, penicillin 5 units $/ \mathrm{ml}$, and streptomycin $5 \mu \mathrm{g} / \mathrm{ml}$ ). The number of viable cells was determined by the trypan blue exclusion method in a hemacytometer ( $>90 \%$ viable). A cell suspension of $2.5-3 \times 10^{6}$ live cells $/ \mathrm{ml}$ was prepared and plated in $200 \mathrm{ml}$ tissue culture flasks $\left(75 \mathrm{~cm}^{2}\right.$ growth area; Falcon, Oxnard, $\mathrm{CA})$ in volumes of $10 \mathrm{ml} /$ flask $\left(0.4 \times 10^{5}\right.$ cells $/ \mathrm{cm}^{2}$ growth area) (Trimmer et al., 1984). The cells were cultured at $37^{\circ} \mathrm{C}$ in $5 \% \mathrm{CO}_{2}$ and $95 \%$ air with $100 \%$ humidity for $12-14 \mathrm{~d}$ until confluence. The cells were then shaken at $270 \mathrm{rpm}$ for $18 \mathrm{hr}$ at $37^{\circ} \mathrm{C}$, and the medium containing suspended cells was removed, discarded, and replaced with new complete medium. The resulting culture consists of more than $95 \%$ of polygonal, flat astroglial cells as confirmed by phase-contrast microscopy and positive immunostaining with antibody against glial fibrillary acid protein (GFAP; McCarthy and de Vellis, 1980). The remaining $<5 \%$ of cells consisted of process bearing cells (about half of which were astrocytes and half oligodendrocytes) and fibroblasts. The cultures were used for the studies within 1 week of "purification" and at least $1 \mathrm{~d}$ after medium change.

Fibroblast cultures. Fibroblasts were also cultured from the meninges of the same neonatal rats used for culture of astroglial cells. Meningeal coverings peeled from the cerebral cortices were cut into pieces of approximately $1 \times 1 \mathrm{~mm}$ and incubated in $0.25 \%$ trypsin and $0.02 \%$
EDTA solution at room temperature for $30 \mathrm{~min}$. Trypsin activity was terminated by the addition of twice the volume of Dulbecco's modified Eagle medium (DME; GIBCO) and 10\% FCS. The tissue pieces were mechanically triturated and filtered through a $130 \mu \mathrm{M}$ Nitex monofilament screen, and the filtrate was centrifuged. The resulting cell pellet was gently vortexed, and the cells were resuspended in DME $+10 \%$ FCS medium. Viable cell density was determined by trypan blue exclusion method and then plated in $200 \mathrm{ml}$ tissue culture flasks (Falcon) at a cell density of $1 \times 10^{6}$ live cells $/ \mathrm{ml}(10 \mathrm{ml} /$ flask $)$. The cells were cultured at $37^{\circ} \mathrm{C}$ in $5 \% \mathrm{CO}_{2} / 95 \%$ air and $100 \%$ humidity. Once confluent, the cultures were passed at a dilution of 1:4. The cells were used for binding and affinity cross-linking studies between the third and sixth passages. Fibroblasts from normal rat kidney (NRK cells, Tissue Culture Facility, Lineberger Cancer Research Center, UNC) were cultured and studied in an identical manner.

${ }^{125} I-S m / I G F$ binding autoradiography. Purified astroglial cells were washed once in saline $1\left(138 \mathrm{mM} \mathrm{NaCl}, 5.4 \mathrm{mM} \mathrm{KCl}, 1.1 \mathrm{mM} \mathrm{Na}_{2} \mathrm{HPO}_{4}\right.$, $1.1 \mathrm{mM} \mathrm{KH}_{2} \mathrm{PO}_{4}$, and $22 \mathrm{~mm}$ glucose) and treated with $0.1 \%$ trypsin and $0.02 \%$ EDTA solution $(5.0 \mathrm{ml} /$ culture flask $)$ at $37^{\circ} \mathrm{C}$ for $15 \mathrm{~min}$. Trypsin activity was then terminated by the addition of twice the volume of complete medium. The cell suspension was triturated and centrifuged, and the cell pellet was resuspended in complete medium. Viable cell count was performed and appropriate dilutions made to give a final cell concentration of $1 \times 10^{4}$ viable cells $/ \mathrm{ml}$. The cell suspension was then plated onto $15 \mathrm{~mm}$ Thermanox tissue culture coverslips (Lux, Naperville, IL) in 24 well tissue culture plates (Falcon) in volumes of $0.5 \mathrm{ml} /$ well. The cells were then cultured for $48 \mathrm{hr}$ and changed into serumfree medium (BME with penicillin, 5 units $/ \mathrm{ml}$, and streptomycin, $5 \mu \mathrm{g} /$ $\mathrm{ml}$ ) for another $48 \mathrm{hr}$ prior to the binding studies.

The coverslips were washed with $0.1 \mathrm{M}$ HEPES buffer, pH $8.0(0.1$ м HEPES, $0.12 \mathrm{~m} \mathrm{NaCl}, 5 \mathrm{~mm} \mathrm{KCl}, 1.2 \mathrm{~mm} \mathrm{MgSO}_{4}, 8 \mathrm{~mm}$ dextrose, and $10 \mathrm{mg} / \mathrm{ml} \mathrm{BSA}$ ) at $4^{\circ} \mathrm{C}$. The cells were then incubated at $4^{\circ} \mathrm{C}$. with ${ }^{125} \mathrm{I}-\mathrm{Sm}-\mathrm{C}$ or ${ }^{125} \mathrm{I}-\mathrm{IGF}$ II $\left(5 \times 10^{-12} \mathrm{M}\right.$ in $0.5 \mathrm{ml} 0.1 \mathrm{M}$ HEPES buffer $)$ with or without an excess of unlabeled peptide for times of $15 \mathrm{~min}$ to $24 \mathrm{hr}$. To study internalization, incubation was also performed at 22 and at $37^{\circ} \mathrm{C}$ for varying lengths of time. At the end of the incubation period, binding was terminated by aspirating the incubating medium and washing 3 times with cold Hank's balanced salt solution. The cells were then fixed with $4 \%$ paraformaldehyde in $70 \mathrm{~mm}$ phosphate buffer at room temperature for $30 \mathrm{~min}$. The cells were washed with PBS, dehydrated through an alcohol series, and then air-dried or immunostained by either the avidin-biotin technique (Towle et al., 1984) or the immunofluorescence technique (McCarthy, 1983), using a primary antibody against glial fibrillary acid protein (GFAP; Accurate Chemical and Scientific Co., Westbury, NY). The coverslips were coated with nuclear track emulsion (NTB 2 or 3, Fastman Kodak Co., Rochester, $\mathrm{NY}$ ) and exposed for varying lengths of time at $4^{\circ} \mathrm{C}$. The coverslips were then developed with Kodak D19 developer diluted $1: 1$ (vol : vol) with distilled water, fixed, washed thoroughly, counterstained with methyl green pyronin or toluidine blue, dehydrated through ascending alcohol series and xylene, mounted with Permount (Fisher), and coverslipped.

Binding studies. A cell suspension of purified astroglial cells was prepared as above in a final concentration of $3 \times 10^{5} \mathrm{cells} / \mathrm{ml}$ and then subplated into 48 well tissue culture plates (Costar, Cambridge, MA; 1 $\mathrm{cm}^{2}$ growth area per well) at $0.4 \mathrm{ml} /$ well $(120,000$ cells $/$ well). The cells were cultured for $48 \mathrm{hr}$ and changed into serum-free medium (BME) for $48 \mathrm{hr}$. Cells from representative wells were brought into suspension with trypsin EDTA solution, and viable cell counts performed.

The plated cells were washed with $0.1 \mathrm{M}$ HEPES buffer with BSA 10 $\mathrm{mg} / \mathrm{ml}, \mathrm{pH} 8.0$, and then incubated with ${ }^{125} \mathrm{I}-\mathrm{Sm} / \mathrm{IGFs}$ or ${ }^{125} \mathrm{I}$-insulin in $0.1 \mathrm{ml}$ buffer at $4^{\circ} \mathrm{C}$. In the initial binding studies to determine saturability, ${ }^{125} \mathrm{I}-\mathrm{Sm}-\mathrm{C} / \mathrm{IGF}$ I concentrations were varied from $5 \times 10^{-11}$ to $3 \times 10^{-9} \mathrm{M}$ and incubated for $3 \mathrm{hr}$. In studies of the time course of binding, labeled peptides $(50,000 \mathrm{cpm} /$ well, $20 \mathrm{fmol})$ were added to each well and incubated for varying lengths of time from $15 \mathrm{~min}$ to 24 hr. To test the reversibility of binding, the incubating solution was aspirated after $4 \mathrm{hr}$ of binding, and an excess of unlabeled peptide (10 $\mu \mathrm{g} / \mathrm{ml}$ ) in HEPES buffer was added. In the competition studies ${ }^{125} \mathrm{I}-\mathrm{Sm} /$ IGF binding was determined in the presence of graded concentrations of unlabeled peptides (Sm-C/IGF I, IGF II, MSA, and insulin) at $4^{\circ} \mathrm{C}$ for $6 \mathrm{hr}$. Nonspecific binding for all the studies was determined as the binding in the presence of an excess of unlabeled peptides $(10 \mu \mathrm{g} / \mathrm{ml})$. Binding was terminated by the aspiration of the incubating solution and washing the cultures thoroughly with cold PBS 3 times. The cells were then solubilized with $0.1 \mathrm{~N}$ sodium hydroxide and $1 \%$ SDS for $15 \mathrm{~min}$ at room temperature, the cell lysate transferred to test tubes, and the 

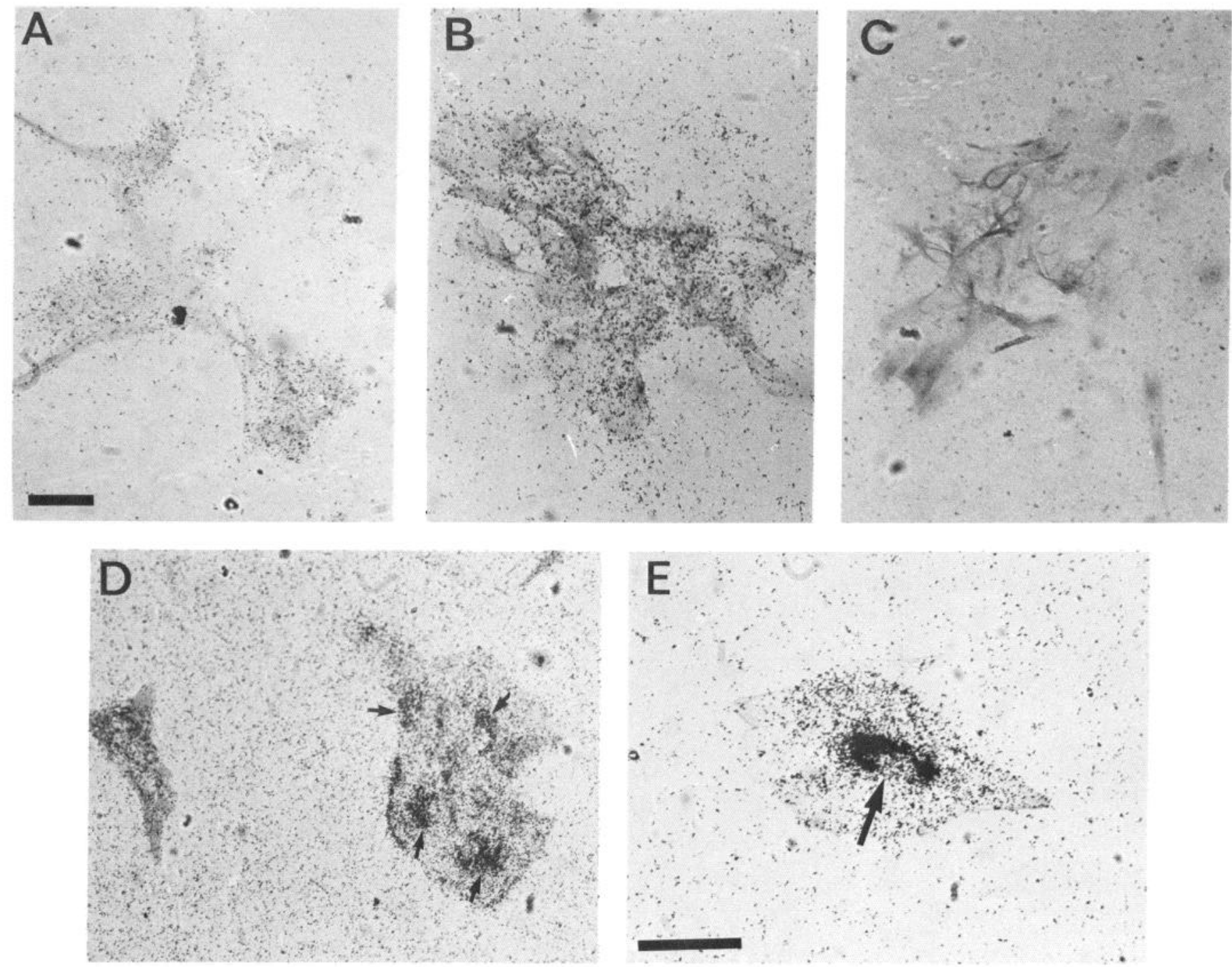

Figure 1. Photomicrographs of autoradiographs showing ${ }^{125}$ I-Sm-C/IGF I binding on sparsely plated astroglial cells. Astroglia were immunocytochemically stained by the avidin-biotin-peroxidase technique with antibody against GFAP. $A$, Cluster of astroglial cells incubated with ${ }^{125} I-S m$ $\mathrm{C} / \mathrm{IGF}$ I for $1 \mathrm{hr}$ at $4^{\circ} \mathrm{C}$. B. Incubated for $6 \mathrm{hr}$ at $4^{\circ} \mathrm{C}$. Incubation for $24 \mathrm{hr}$ at $4^{\circ} \mathrm{C}$ did not increase the autoradiographic signal significantly. $C$, Incubation for $6 \mathrm{hr}$ at $4^{\circ} \mathrm{C}$ in the presence of $10 \mu \mathrm{g} / \mathrm{ml}$ of unlabeled Sm-C/IGF I. D, Incubated for $4 \mathrm{hr}$ at $22^{\circ} \mathrm{C}$. Arrows indicate aggregation of radiolabel in and around the nuclei, suggesting internalization. $E$, Higher magnification of a single astroglial cell showing apparent internalization of the radiolabel after incubation at $22^{\circ} \mathrm{C}$ for $4 \mathrm{hr}$. Arrow indicates aggregation of radiolabel in and around the nucleus. Calibration bar, $50 \mu \mathrm{m}$.

cell associated radioactivity determined in a gamma spectrometer (Hewlett Packard Co., Corvallis, OR). Binding was analyzed by the method of Scatchard (1949) according to the "trial and error" technique (Rosenthal, 1967; Pennock, 1973). Using a computer program, several plots were generated from the estimated $K_{a}$ and $R_{0}\left(B_{\max }\right)$ values for each binding site and "goodness" to fit was determined with the observed values.

Affinity cross-linking. A modification of the methods described by Wilkins and D'Ercole (1985) and Adams et al. (1983) was used to affinity cross-link ${ }^{125} \mathrm{I}$-Sm/IGFs and ${ }^{125} \mathrm{I}$-insulin to receptors on astroglial cells. Purified astroglial cells were subplated onto $35 \mathrm{~mm}$ tissue culture dishes (Falcon) at a cell density of $1.0 \times 10^{6}$ cells/dish in $2 \mathrm{ml}$ of BME $+10 \%$ FCS. The cells were grown to confluence, usually in $48-72 \mathrm{hr}$. The culture medium was then changed to serum-free BME and then incubated at $37^{\circ} \mathrm{C}$ for another $48 \mathrm{hr}$. The cultures were washed twice with $0.1 \mathrm{~m}$ HEPES buffer, $\mathrm{pH} 8.0$, with BSA $10 \mathrm{mg} / \mathrm{ml}$ and incubated with ${ }^{125} \mathrm{I}-\mathrm{Sm} / \mathrm{IGF}$ or ${ }^{125} \mathrm{I}$-insulin $\left(4-5 \times 10^{5} \mathrm{cpm} / \mathrm{dish}\right)$ in the same HEPES buffer, with or without varying concentrations of unlabeled peptides at $4^{\circ} \mathrm{C}$ for $16-18 \mathrm{hr}$. The incubating solution was then aspirated, and cultures were washed 3 times with cold $\left(4^{\circ} \mathrm{C}\right)$ HEPES buffer, $\mathrm{pH} 7.4$, without BSA, to remove the unbound radiolabel. ${ }^{125} \mathrm{I}-\mathrm{Sm}-\mathrm{C} / \mathrm{IGF} \mathrm{I}$, which was bound to surface receptor protein, was affinity cross-linked using the cross-linking agent, disuccinimidyl suberate (DSS), in a final concentration of $0.1 \mathrm{~mm}$ by incubation at $22^{\circ} \mathrm{C}$ for $10 \mathrm{~min}$. The reaction was then stopped by aspiration of the DSS solution and addition of $1 \mathrm{ml}$ of $10 \mathrm{~mm}$ Tris $\mathrm{HCl}$. The cells were then scraped from the bottom of the dish using a disposable plastic spatula; solubilized in $2 \%$ SDS, $12.5 \mathrm{~mm}$ Tris, $0.002 \%$ bromophenol blue, and $8 \%$ glycerol with or without the reducing agent dithiothrietol $(100 \mathrm{~mm})$; and boiled for $5 \mathrm{~min}$. The proteins were then separated on a 3-14\% linear gradient SDS-PAGE using a Tris-glycine buffer, $\mathrm{pH} 8.0$, according to the method described by Laemmli (1970). The gel was then fixed in $10 \%$ acetic acid and $30 \%$ methanol solution, washed, dried, and exposed to an X-ray film (Kodak XAR or XRP) between 2 intensifying screens (Dupont) for 1-2 weeks. The molecular weights of the standards used for SDS-PAGE were myo$\sin (200,000 \mathrm{Da})$, phosphorylase-B $(97,400 \mathrm{Da}), \mathrm{BSA}(68,000 \mathrm{Da})$, ovalbumin $(43,000 \mathrm{Da}), \alpha$-chymotrypsin $(25,700 \mathrm{Da}), \beta$-lactglobulin $(18,400$ $\mathrm{Da})$, and lysozyme (14,300 Da) (Bethesda Research Laboratories, Bethesda, MD).

${ }^{3} \mathrm{H}$-thymidine incorporation studies. To test the mitogenic actions of $\mathrm{Sm} / \mathrm{IGFs}$ and insulin on the astroglial cells, ${ }^{3} \mathrm{H}$-thymidine (TdR) incorporation studies were performed according to a modification of the method described by Russell et al. (1984). The purified astroglial cells were treated with $0.1 \%$ trypsin and $0.02 \%$ EDTA solution, suspended 
Figure 2. ${ }^{125} \mathrm{I}-\mathrm{Sm}-\mathrm{C} / \mathrm{IGF}$ I binding to astroglial monolayers. Specific binding of ${ }^{125} \mathrm{I}-\mathrm{Sm}-\mathrm{C} / \mathrm{IGF} \mathrm{I}$ to astroglial monolayers (each point represents the mean of 6 replicates) increased as the concentration of radiolabel was increased up to $1.5 \times 10^{-9} \mathrm{M}$. Further increase in radiolabel concentration did not increase specific binding, indicating saturability of ${ }^{125 I-S m-C / I G F ~ I ~ b i n d i n g . ~}$

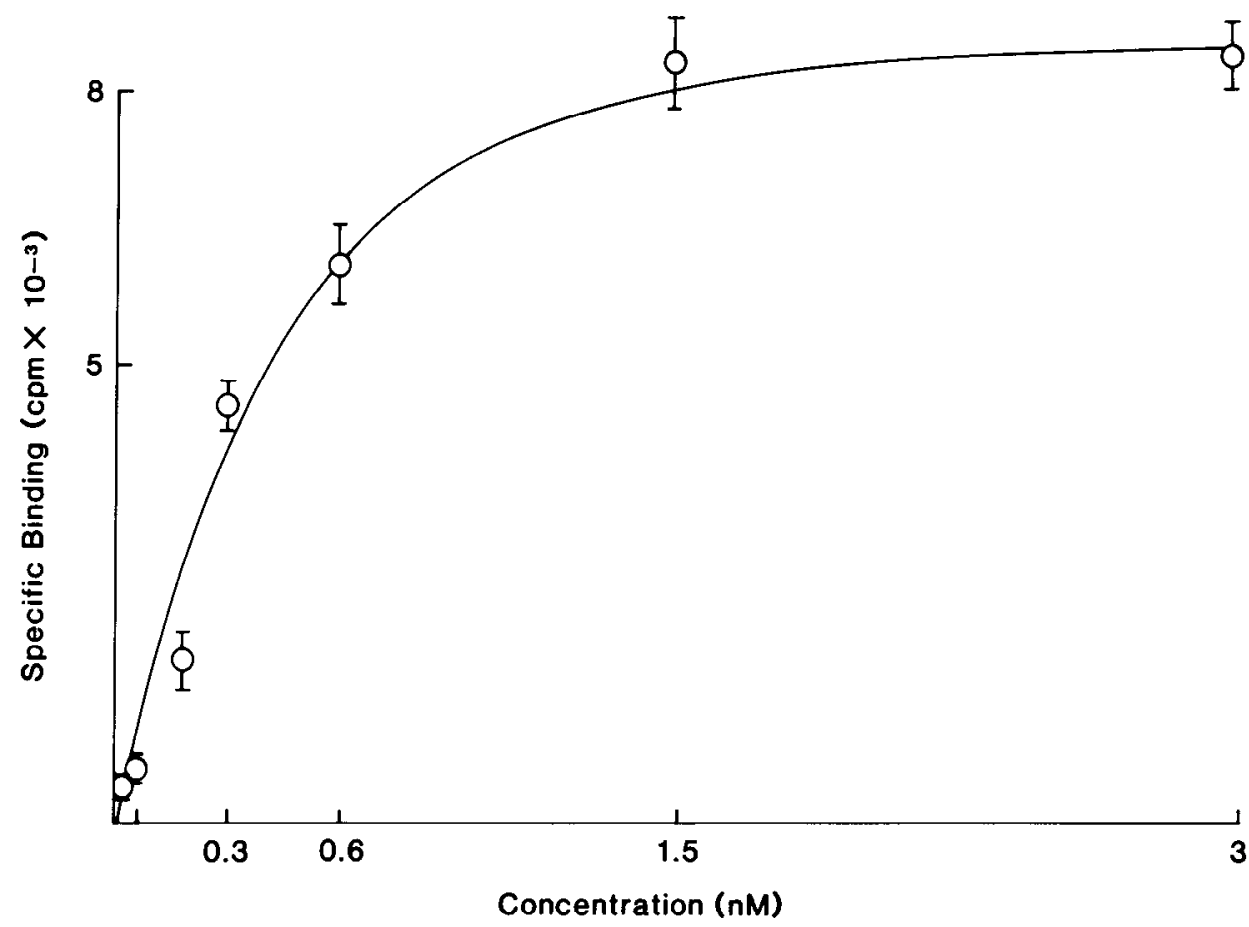

in BME and $10 \%$ FCS medium, and plated onto 48 well tissue culture plates (Costar) at a cell density of $1-1.2 \times 10^{5}$ cells/well. The cells were cultured at $37^{\circ} \mathrm{C}$ for $48 \mathrm{hr}$, following which the medium was changed to serum-free BME and incubated for another $48 \mathrm{hr}$. The cultures were then washed with a fresh BME and BSA solution and were then incubated with varying concentrations of Sm/IGF I, IGF II, MSA III.2, and insulin, while the control cultures were incubated only with BME and BSA $2 \mathrm{mg} / \mathrm{ml}$ solution. After incubation for $22 \mathrm{hr},{ }^{3} \mathrm{H}-\mathrm{TdR}(0.5 \mu \mathrm{Ci} /$ well) was added to the cultures and the incubation was continued for another $2 \mathrm{hr}$. The reaction was stopped by aspiration of the incubating solution and washing with cold $\left(4^{\circ} \mathrm{C}\right)$ PBS 3 times. The cultures were

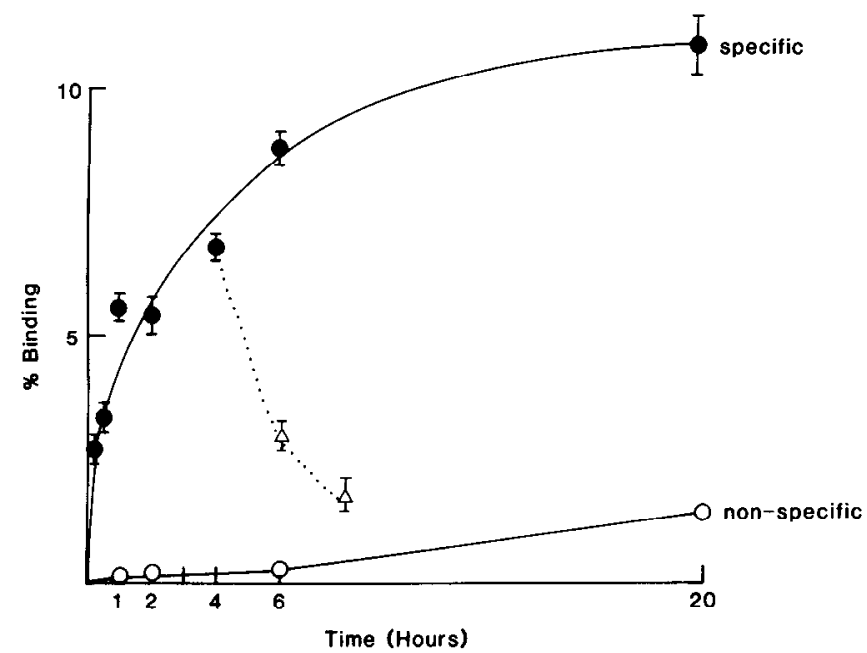

Figure 3. Time course of ${ }^{125} \mathrm{I}-\mathrm{Sm}$-C/IGF I binding to astroglial cells. ${ }^{125} \mathrm{I}-\mathrm{Sm}$-C/IGF-I, $20 \mathrm{fmol} /$ well, was incubated at $4^{\circ} \mathrm{C}$ on plated astroglial cells and binding terminated at the described time points. Each point represents the mean of 6 replicates. Nonspecific binding, determined in the presence of an excess of unlabeled Sm-C/IGF I, was $0.8 \%$ at $6 \mathrm{hr}$ and $1.8 \%$ at $20 \mathrm{hr}$. Specific binding $(\longrightarrow)$ increased rapidly up to 6 $\mathrm{hr}$, then asymptotically up to $20 \mathrm{hr}$. Nonspecific binding in the presence of $1 \mu \mathrm{g} / \mathrm{ml}$ unlabeled Sm-C/IGF I is also shown $\left(\mathrm{O}_{-}\right.$). Reversibility of binding is shown by the ${ }^{125}$ I-Sm-C/IGF I remaining bound $(\Delta-\Delta)$, when fresh medium containing $2 \mu \mathrm{g} / \mathrm{ml}$ of unlabeled $\mathrm{Sm}-\mathrm{C} /$ IGF I was added after $4 \mathrm{hr}$. then incubated with $5 \%$ trichloracetic acid (TCA) at $4^{\circ} \mathrm{C}$ for $20 \mathrm{~min}$, the TCA solution aspirated, and cultures washed again with fresh $5 \%$ TCA. After removal of the TCA solution, the cultures were solubilized in $1 \%$ SDS and $0.1 \%$ sodium hydroxide. The resultant solution was added to $10 \mathrm{ml}$ of complete counting cocktail (Research Products International Corp., Elk Grove Village, IL) and counted in a scintillation counter (LKB Instruments, Gaithersburg, MD).

\section{Results}

Autoradiographic studies of ${ }^{125} \mathrm{I}-\mathrm{Sm} / \mathrm{IGF}$ binding

Specific binding of ${ }^{125}$ I-Sm-C/IGF by putative cell-surface receptors of cultured astroglial cells was shown by association of autoradiographic silver grains with sparsely plated astroglial cells (Fig. 1, $A, B$ ) and the reduction of such signals when the cells were incubated in the presence of excess of unlabeled Sm-C/ IGF I, $10 \mu \mathrm{g} / \mathrm{ml}$ (Fig. 1C). The cells were shown to be astroglia by their morphology and positive immunostaining with antiGFAP antibody. Receptor binding autoradiography with other radioligands ( ${ }^{125}$ I-IGF II and ${ }^{125}$ I-MSA) gave similar results.

${ }^{125} \mathrm{I}-\mathrm{Sm}-\mathrm{C} / \mathrm{IGF}$ I bound to astroglial cells in a time-dependent manner. When incubations were performed at $4^{\circ} \mathrm{C}$, there was an increase in the density of silver grains associated with the cells for up to $6 \mathrm{hr}$ (Fig. 1, $A, B$ ). No further increase was observed when incubation was extended to $24 \mathrm{hr}$. At 22 and $37^{\circ} \mathrm{C}$, an increase in this autoradiographic signal was seen up to $2 \mathrm{hr}$ of incubation. Within $3 \mathrm{hr}$, the silver grains appeared to accumulate on and around the nuclear region and increased in density by $6 \mathrm{hr}$ (Fig. 1, D, E). The latter finding suggests internalization of the radiolabeled peptide, a phenomenon known to occur with insulin and peptide growth factors (Gorden et al., 1978; Carpentier et al., 1981). Positive autoradiography with both radiolabeled Sm-C/IGF I and IGF II suggest that astroglia possess both receptor subtypes, a finding supported by the crosslinking studies (see below). In addition, all the flat, polygonal astroglia that were GFAP immunopositive showed binding to both radiolabeled peptides. The few process-bearing GFAPpositive cells that remained in the cultures also showed binding to both ligands. 


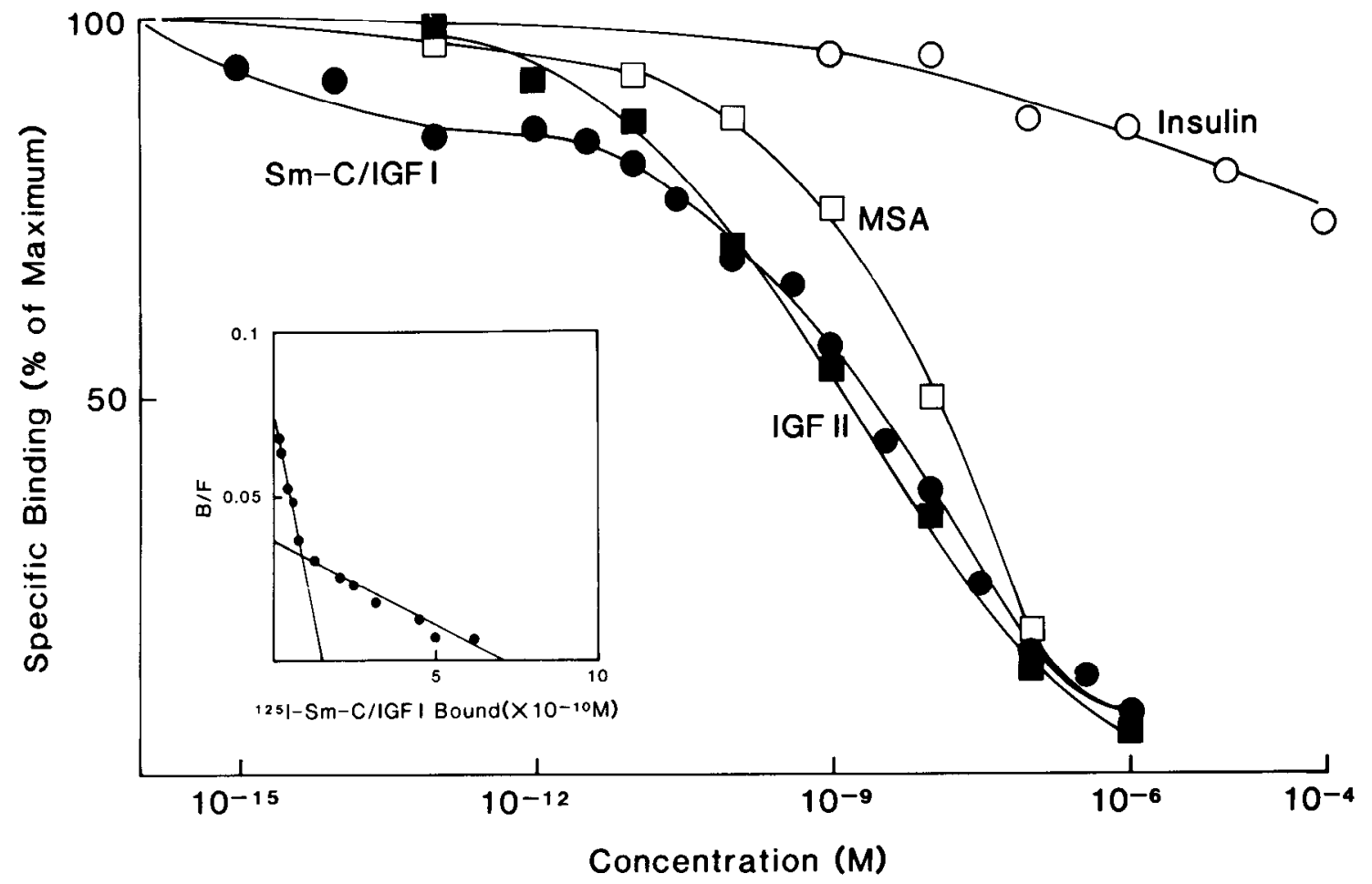

Figure 4. Competition for ${ }^{125} \mathrm{I}-\mathrm{Sm}-\mathrm{C} / \mathrm{IGF}$ I binding to astroglial cells by unlabeled Sm-C/IGF I, IGF II, MSA, and insulin. Binding is expressed as the percentage of maximum specific binding (10\%). Each point is the mean of 3 replicates. The SEM of each data point was less than $5 \%$. Insert shows the computer-generated Scatchard analysis of ${ }^{125} \mathrm{I}-\mathrm{Sm}-\mathrm{C} / \mathrm{IGF}$ I binding. For high-affinity binding site, $K_{a}=0.5 \times 10^{9} \mathrm{M}^{-1}$ and $R_{0}=4.5 \times$ $10^{4}$ receptors/cell; for lower-affinity binding site, $K_{a}=0.05 \times 10^{9} \mathrm{M}^{-1}$ and $R_{0}=21 \times 10^{4}$ receptors $/$ cell.

\section{Quantification of ${ }^{125} I-S m / I G F$ and ${ }^{125} I$-insulin binding}

In order to quantify $\mathrm{Sm} / \mathrm{IGF}$ receptor binding, studies were carried out to allow direct counting of bound radioligand and Scatchard analysis. ${ }^{125} \mathrm{I}-\mathrm{Sm}-\mathrm{C} / \mathrm{IGF}$ I binding to astroglial cells was saturable. When the ${ }^{125} \mathrm{I}-\mathrm{Sm}-\mathrm{C} / \mathrm{IGF}$ I concentration was varied from 0.05 to $3.0 \mathrm{nM}$, specific binding increased exponentially in concentrations up to $0.6 \mathrm{nM}$ and was maximal at $1.5 \mathrm{nM}$ (Fig. 2). Specific binding of ${ }^{125} \mathrm{I}-\mathrm{Sm}-\mathrm{C} / \mathrm{IGF}$ I increased linearly with time of incubation up to $6 \mathrm{hr}$, and no further increase occurred with time up to $24 \mathrm{hr}$ (Fig. 3). Also, ${ }^{125} \mathrm{I}-\mathrm{Sm}$ C/IGF I binding was reversible (Fig. 3). When the incubating solution was removed after $4 \mathrm{hr}$ of incubation, fresh buffer with an excess of unlabeled Sm-C/IGF I $(10 \mu \mathrm{g} / \mathrm{ml})$ added, and the radioactivity remaining bound to the cultures measured, the cell-associatcd radioactivity was reduced significantly with subsequent incubation. Radiolabeled IGF II and MSA demonstrated similar specific binding under identical conditions. Radiolabeled insulin, however, had specific binding of less than $0.5 \%$; therefore, further studies were not performed.

To test the specificity of ${ }^{125}$ I-Sm-C/IGF I binding, competition studies were performed with unlabeled Sm-C/IGF I, IGF II, MSA, and insulin (Fig. 4). Half-maximal displacement of ${ }^{125}$ I$\mathrm{Sm}-\mathrm{C} / \mathrm{IGF}$ I binding by unlabeled Sm-C/IGF I and IGF II occurred at $1 \times 10^{-9} \mathrm{M}$, while half-maximal displacement was about 10 -fold less sensitive to unlabeled MSA, occurring at $10^{-8}$ M. Unlabeled insulin, at the highest concentration tested $(1 \times$ $10^{-4} \mathrm{M}$ ), could produce only $20 \%$ displacement. Despite the sensitivity of ${ }^{125}$ I-Sm-C/IGF I binding to competition with IGF II, $15-20 \%$ of this binding was consistently displaced with very low concentrations of unlabeled Sm-C/IGF I $\left(10^{-10}-10^{-14} \mathrm{M}\right)$.
Scatchard analysis of Sm-C/IGF I binding revealed a curvilinear plot that was consistent with the presence of more than 1 class of distinct receptors (Fig. 4, insert). Assuming 2 classes of receptors, affinity constant $\left(K_{a}\right)$ and binding capacity $\left(R_{0}\right)$ were $K_{a}=0.5 \times 10^{9} \mathrm{M}^{-1}, R_{0}=4.5 \times 10^{4}$ receptors/cell for the highaffinity receptor, and $K_{a}=0.05 \times 10^{9} \mathrm{M}^{-1}, R_{0}=21 \times 10^{4}$ receptors/cell for the lower-affinity receptor.

Competition studies were also performed with ${ }^{125}$ I-IGF II and 125I-MSA. The displacement curves of each were similar, with unlabeled IGF II and MSA being equipotent and unlabeled SMC/IGF I being about 10 times less potent (Figs. 5, 6). Scatchard analysis of each yielded nearly linear plots that were virtually identical, consistent with a single class of receptors (Figs. 5 and 6 , inserts). The affinity constants $\left(K_{a}\right)$ were calculated to be $0.18 \times 10^{9} \mathrm{M}^{-1}$ and $0.2 \times 10^{9} \mathrm{M}^{-1}$, and the binding capacities $16.5 \times 10^{4}$ receptors/cell and $15 \times 10^{4}$ receptors/cell for ${ }^{125}$ IIGF II and ${ }^{125}$ I-MSA, respectively.

\section{Characterization of $S m / I G F$ and insulin receptors by affinity cross-linking}

Affinity cross-linking of ${ }^{125} \mathrm{I}-\mathrm{Sm}$-C/IGF I to astroglial cell-surface receptors and analysis on SDS-PAGE under nonreducing conditions showed radiolabeled protein bands with $M_{r}$ of 220,000 $(220 \mathrm{~K})$ and greater than $300 \mathrm{~K}$. These bands were greatly reduced in intensity when incubation was performed in the presence of $100 \mathrm{ng} / \mathrm{ml}$ unlabeled Sm-C/IGF I (Fig. 7). When SDS-PAGE was performed under reducing conditions, radiolabeled bands of $M_{r} 260 \mathrm{~K}$ and $130 \mathrm{~K}$ were observed. Both were inhibited by coincubation with $100 \mathrm{ng} / \mathrm{ml}$ of unlabeled Sm-C/IGF I. When incubation was performed in the presence of graded concentrations of unlabeled Sm/IGFs to assess relative affinity, the in- 


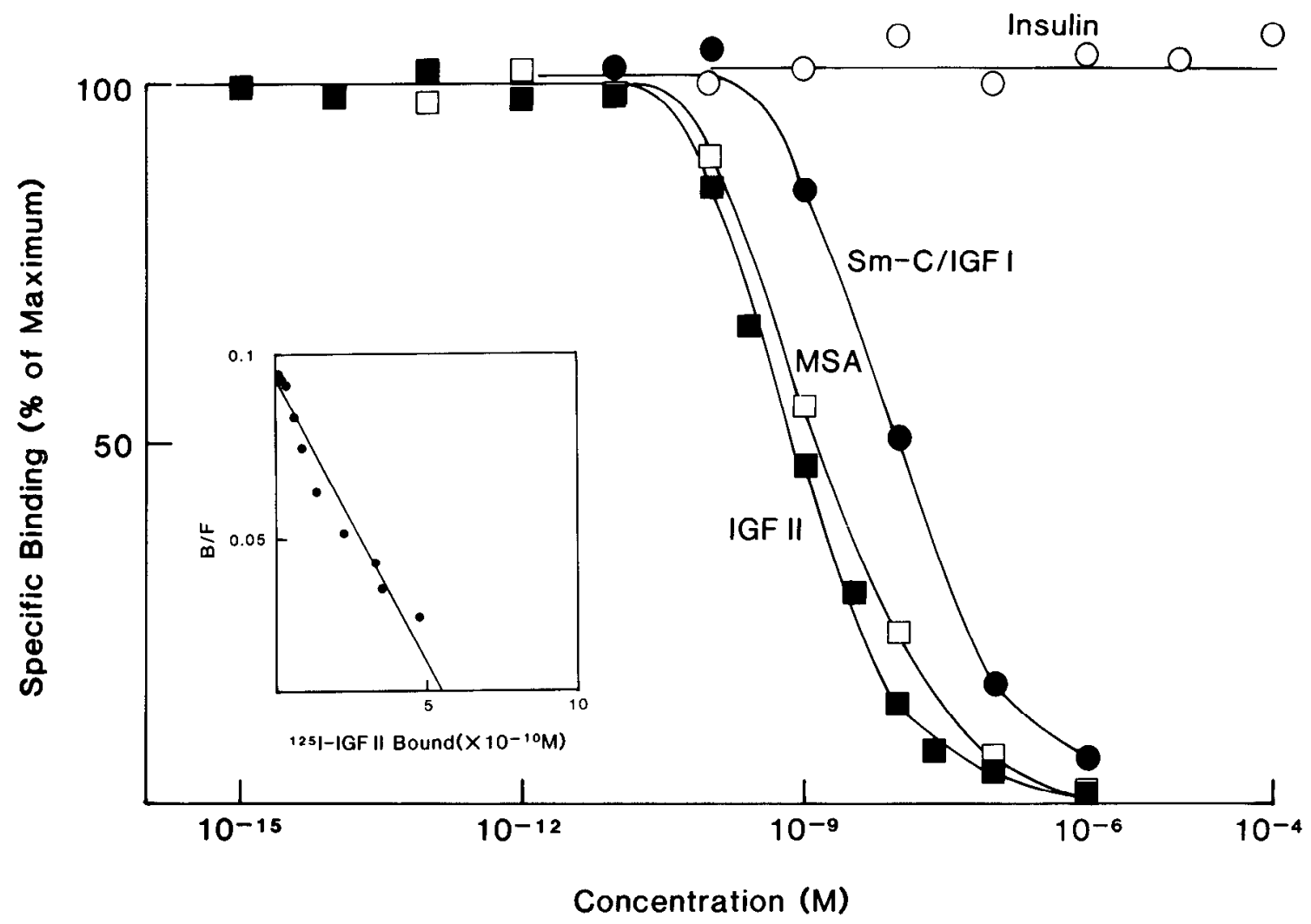

Figure 5. Competition for ${ }^{125}$ I-IGF II binding to astroglial cells by unlabeled Sm-C/IGF I, IGF II, MSA, and insulin. Each point represents the mean of 3 replicates. The SEM of each data point was less than $5 \%$. Insert shows Scatchard analysis of ${ }^{125}$ I-IGF II binding; $K_{a}=0.18 \times 10^{9} \mathrm{M}^{-1}$ and $R_{0}=16.5 \times 10^{4}$ receptors $/$ cell.

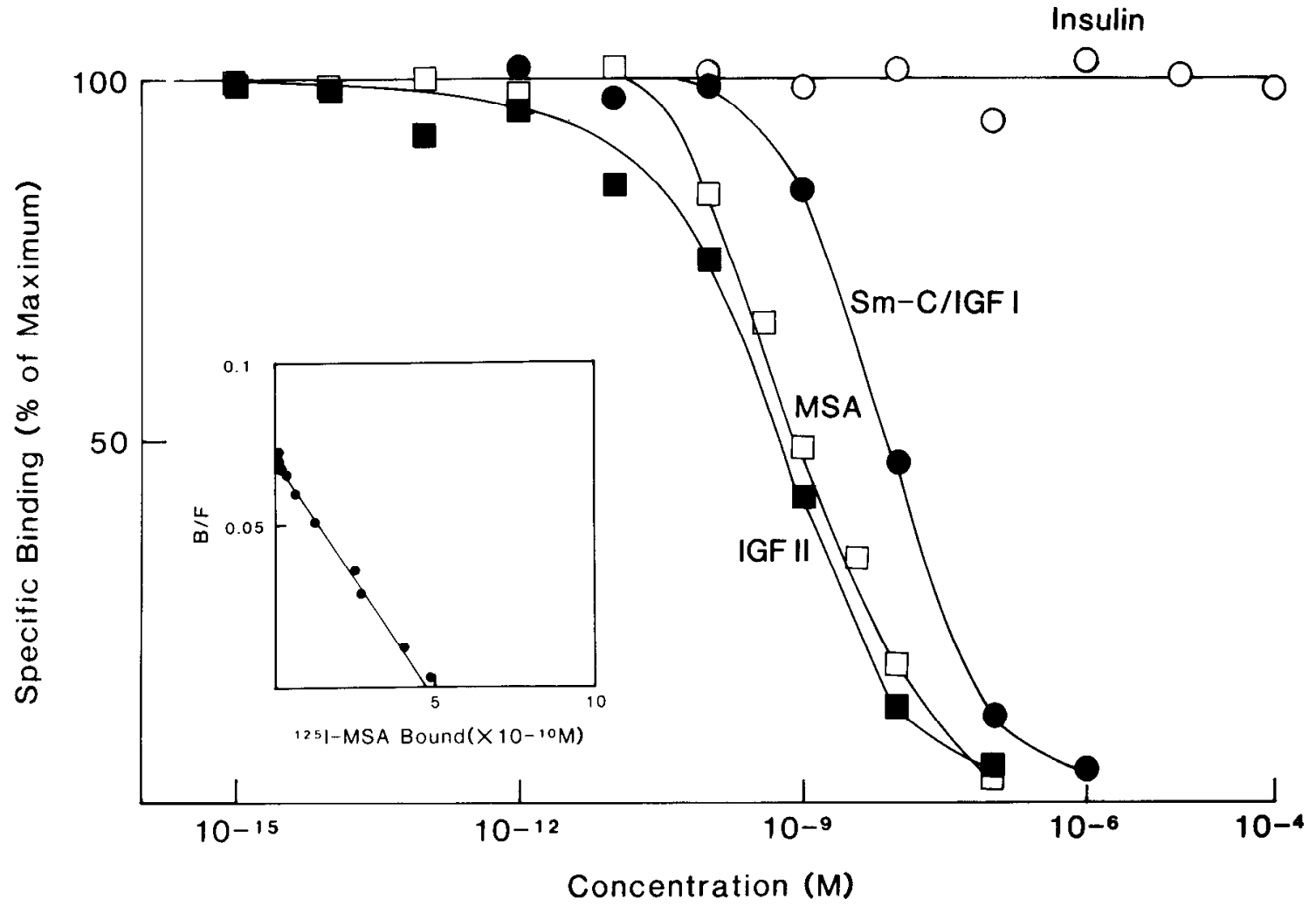

Figure 6. Competition for ${ }^{25}$ I-MSA binding to astroglial cells by unlabeled Sm-C/IGF I, IGF II, MSA, and insulin. Each point is the mean of 3 replicates. The SEM of each data point was less than $5 \%$. Insert shows Scatchard analysis of ${ }^{125} \mathrm{I}-\mathrm{MSA}$ binding; $K_{a}=0.2 \times 10^{9} \mathrm{M}^{-1}$ and $R_{0}=$ $15 \times 10^{4}$ receptors/cell. 


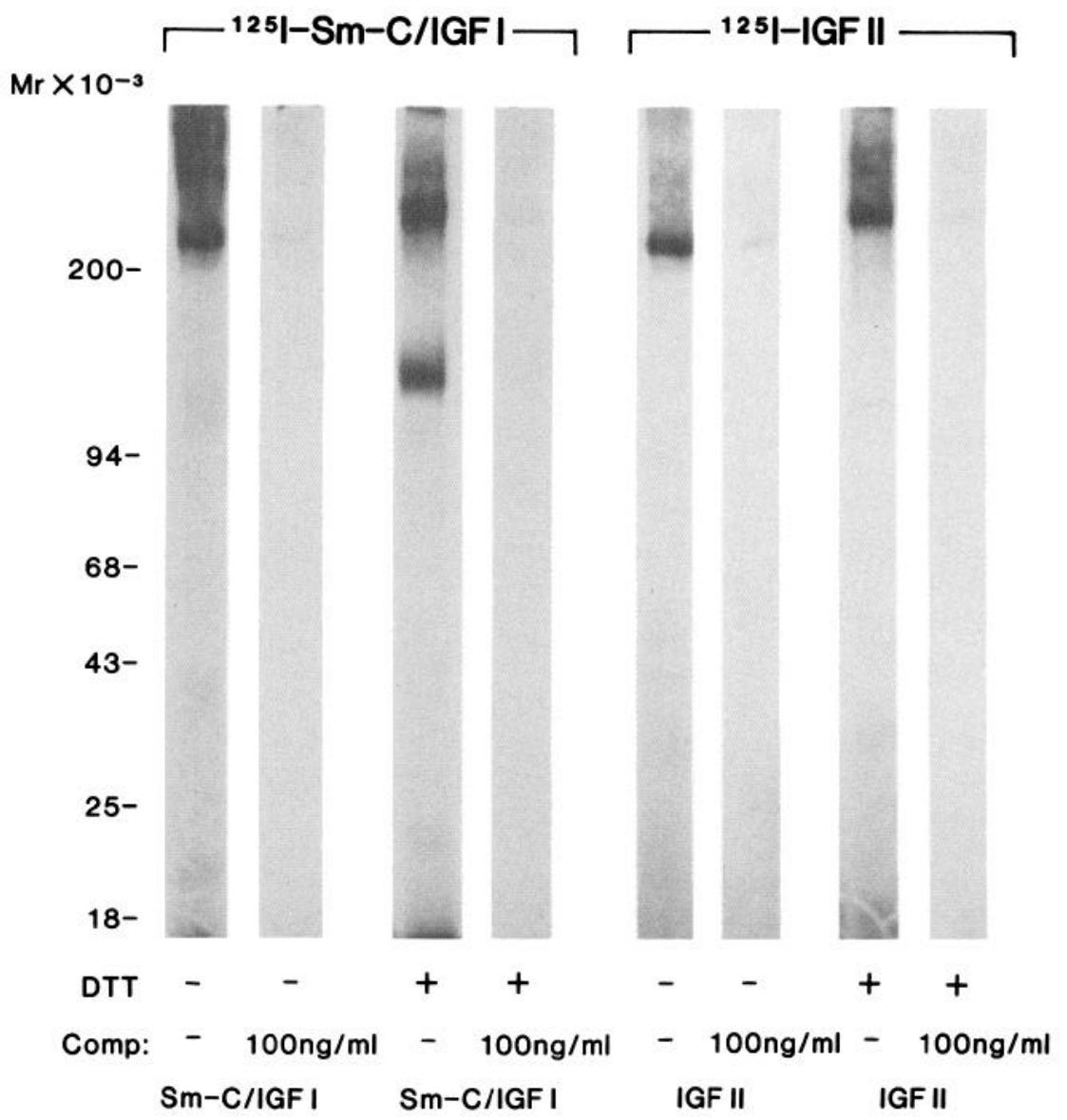

Figure 7. Affinity labeling of ${ }^{125} \mathrm{I}-\mathrm{Sm}$ C/IGF I (4 lanes at left) and ${ }^{125}$ I-IGF II (4 lanes at right) bound to astroglial cells and analyzed on $3-14 \%$ SDS-PAGE under nonreducing conditions $(D T T-)$ and under reducing conditions (DTT + ). Specificity of binding was shown by affinity cross-linking in the presence of $100 \mathrm{ng} / \mathrm{ml}$ (14 $\mathrm{nm})$ of respective unlabeled peptides as indicated. tensities of both bands were diminished in the presence of unlabeled Sm-C/IGF I, IGF II, or MSA (Fig. $8 A$; MSA not shown). The intensity of the $130 \mathrm{~K} M$, band, but not the $260 \mathrm{~K}$ band, was more sensitive to $\mathrm{Sm}-\mathrm{C} / \mathrm{IGF}$ I than to IGF II or MSA and was also diminished when the incubation was performed with a high concentration of unlabeled insulin $(10 \mu \mathrm{g} / \mathrm{ml})$. The $130 \mathrm{~K}$ band thus had affinity characteristics of the type I Sm/IGF receptor (Pilch and Czech, 1979; Chernausek et al., 1981; Czech, 1982) and differed from the $260 \mathrm{~K} M_{r}$ band. The latter was likely to be the type II Sm/IGF receptor because it could be diminished in intensity with both Sm-C/IGF I and IGF II but not with high concentrations of insulin $(10 \mu \mathrm{g} / \mathrm{ml})$ (Kasuga et al., 1981; Massagué et al., 1981). The $M_{r}>300 \mathrm{~K}$ bands observed under nonreducing conditions and the $M_{r} 130 \mathrm{~K}$ band observed under reducing conditions, therefore, appear to represent the type I $\mathrm{Sm} / \mathrm{IGF}$ receptor, while the $M, 220 \mathrm{~K}$ and $260 \mathrm{~K}$ bands under nonreducing and reducing conditions, respectively, represent the type II Sm/IGF receptor (Bhaumick et al., 1981; Chernausek et al., 1981; Kasuga et al., 1981). Astroglial cells therefore appear to possess both type I and II Sm/IGF receptors, and ${ }^{125} \mathrm{I}-\mathrm{Sm}-\mathrm{C} /$ IGF I appears capable of binding to both species.

When ${ }^{125}$ I-IGF II was cross-linked to astroglial cells and analyzed in SDS-PAGE under nonreducing conditions, the radiolabel was associated with a protein band of $M, 220 \mathrm{~K}$ (Fig. 7). The intensity of this band was greatly diminished when incubation was performed in the presence of unlabeled IGF II or MSA. Under reducing conditions, the radiolabel was associated with a protein band of $M, 260 \mathrm{~K}$, and the capacity of unlabeled peptides to obliterate this band was virtually identical to that observed under nonreducing conditions. When incubations were performed in the presence of varied concentrations of unlabeled $\mathrm{Sm} / \mathrm{IGFs}$ or insulin, and analyzed under reducing conditions (Fig. $8 B$ ), unlabeled Sm-C/IGF I diminished the intensity of the $260 \mathrm{~K}$ band; however, its intensity was not reduced by co-incubation with unlabeled insulin, even at a concentration of 10 $\mu \mathrm{g} / \mathrm{ml}$. Our results further support the conclusion that the protein moiety of $M_{r} 220 \mathrm{~K}$ observed under nonreducing conditions migrates at a higher $M_{r}$ of $260 \mathrm{~K}$ under reducing conditions and is the type II Sm/IGF receptor (Massagué et al., 1981). That radiolabeled IGF II was not associated with the $M_{r}>300 \mathrm{~K}$ protein bands under nonreducing conditions, or the $M_{r} 130,000$ band under reducing conditions, suggests that ${ }^{125}$ I-IGF II binds only to type II Sm/IGF receptors in rat astroglial cells. Identical findings were seen when ${ }^{125}$ I-MSA was affinity cross-linked to rat astroglial cells (data not shown). Furthermore, identical observations were made when radiolabeled Sm-C/IGF I, IGF II, and MSA were affinity cross-linked to meningeal fibroblasts derived from neonatal rats and normal rat kidney (NRK) fibroblasts (autoradiograms not shown). These findings suggest that IGF II preferentially binds to type II Sm/IGF receptor in cells derived from rats.

When ${ }^{125}$ I-insulin was affinity cross-linked to astroglial cells and analyzed on SDS-PAGE, the radiolabel was preferentially associated with $M_{r}>300 \mathrm{~K}$ of protein bands under nonreducing conditions (data not shown) and with $M_{r} 260 \mathrm{~K}$ and $130 \mathrm{~K}$ protein bands under reducing conditions (Fig. 9). The intensities of these radiolabeled bands were much less than those seen when ${ }^{125} \mathrm{I}-\mathrm{Sm} / \mathrm{IGFs}$ were cross-linked, 3-fold longer exposure times 


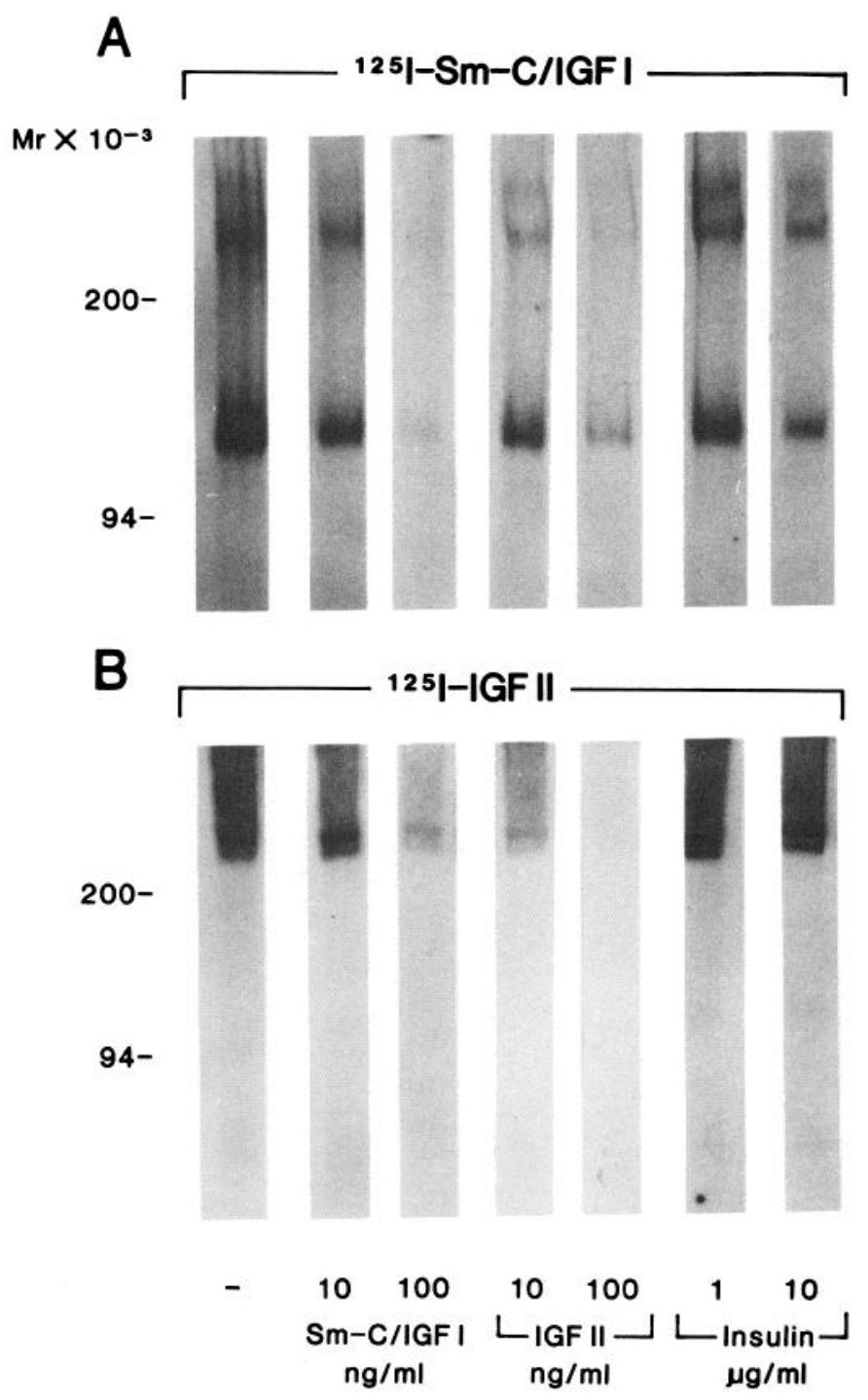

Figure 8. Affinity labeling of ${ }^{125} \mathrm{I}-\mathrm{Sm}-\mathrm{C} / \mathrm{IGF}$ I $(A)$ and ${ }^{125} \mathrm{I}-\mathrm{IGF}$ II $(B)$ bound to astroglial cells in the presence of varying concentrations of unlabeled peptides (Sm-C/IGF I, IGF II, or insulin) and analyzed on 3-14\% SDS-PAGE under reducing conditions. The key below the panel indicates whether unlabeled peptides were present, as well as their identity and concentrations $(\mathrm{ng} / \mathrm{ml} ; 100 \mathrm{ng} / \mathrm{ml}=14 \mathrm{nM})$.

being required for visualization. Because the type I Sm/IGF receptor and insulin receptor have similar subunit structure (Czech, 1982), size characteristics do not discriminate between them, and they must be distinguished on the basis of their relative affinities for Sm-C/IGF I and insulin. The intensity of these bands was diminished, but not obliterated, in the presence of unlabeled insulin, Sm-C/IGF I, IGF II, or MSA. Both bands appeared to be more sensitive to competition with unlabeled Sm-C/IGF I or IGF II than with insulin; however, the concentration of unlabeled Sm-C/IGF I required to obliterate ${ }^{125} \mathrm{I}-$ insulin binding to the $130 \mathrm{~K}$ moiety exceeded that required to obliterate ${ }^{125} \mathrm{I}-\mathrm{Sm}-\mathrm{C} / \mathrm{IGF}$ I binding to the type I Sm/IGF receptor $(500 \mathrm{vs} 100 \mathrm{ng} / \mathrm{ml})$. We believe the $260 \mathrm{~K}$ band represents a dimer of $130 \mathrm{~K}$ subunit, because neither it nor any band less than $300 \mathrm{~K}$ was observed under nonreducing conditions, suggesting that it is not the type II $\mathrm{Sm} / \mathrm{IGF}$ receptor. Our findings suggest that ${ }^{125} \mathrm{I}$-insulin binds predominantly to type I Sm/IGF

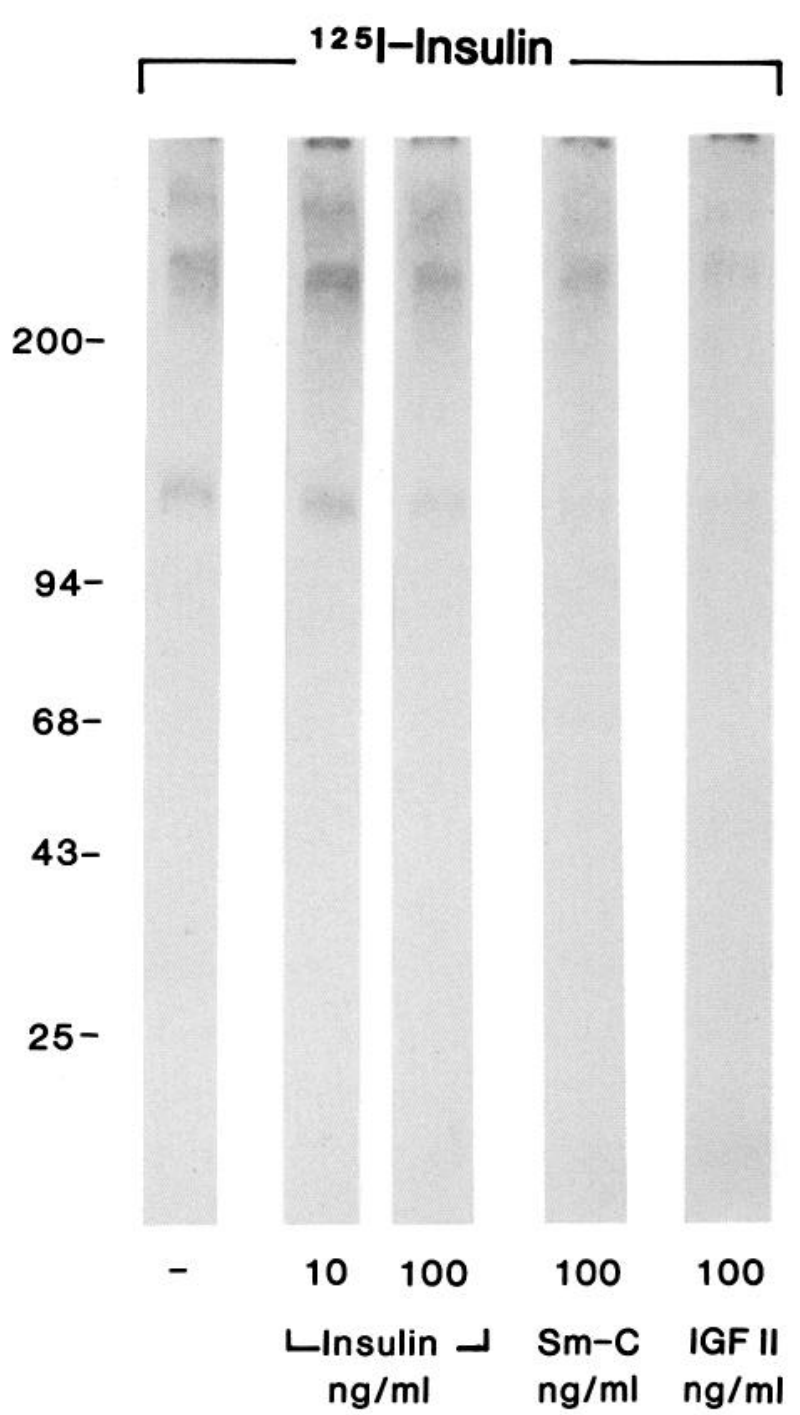

Figure 9. Affinity labeling of ${ }^{125} \mathrm{I}$-insulin bound to astroglial cells and analyzed on 3-14\% SDS-PAGE under reducing conditions. The key below each lane indicates the nature of competition; insulin, $100 \mathrm{ng} /$ $\mathrm{ml}=16 \mathrm{nM} ; \mathrm{Sm}-\mathrm{C} / \mathrm{IGF}$, and IGF I, $100 \mathrm{ng} / \mathrm{ml}=14 \mathrm{nM}$, respectively.

receptors. Specific insulin receptors (Razaida et al., 1980) may also be present on astroglia, but probably are relatively few in number.

\section{${ }^{3} \mathrm{H}$-thymidine incorporation studies}

In order to correlate the receptor binding studies with the biologic actions of Sm/IGFs on astroglial cells, TdR incorporation studies were performed on cells cultured and plated in an identical fashion. DNA synthesis of astroglial cells was stimulated by $\mathrm{Sm} / \mathrm{IGFs}$ and insulin. The maximum TdR incorporation response depended on the peptide studied. MSA stimulated the greatest response, followed by IGF II, Sm-C/IGF I, and then insulin (Fig. 10A). When the same data were plotted as a percentage of the maximal response for each peptide, it appeared that astroglial cells were most sensitive to Sm-C/IGF I and least sensitive to insulin: Half-maximal responses were $0.7 \mathrm{~nm}$ for Sm-C/IGF I, $6.0 \mathrm{~nm}$ for IGF II, $8.0 \mathrm{~nm}$ for MSA, and $14 \mathrm{~nm}$ for insulin (Fig. 10B). 

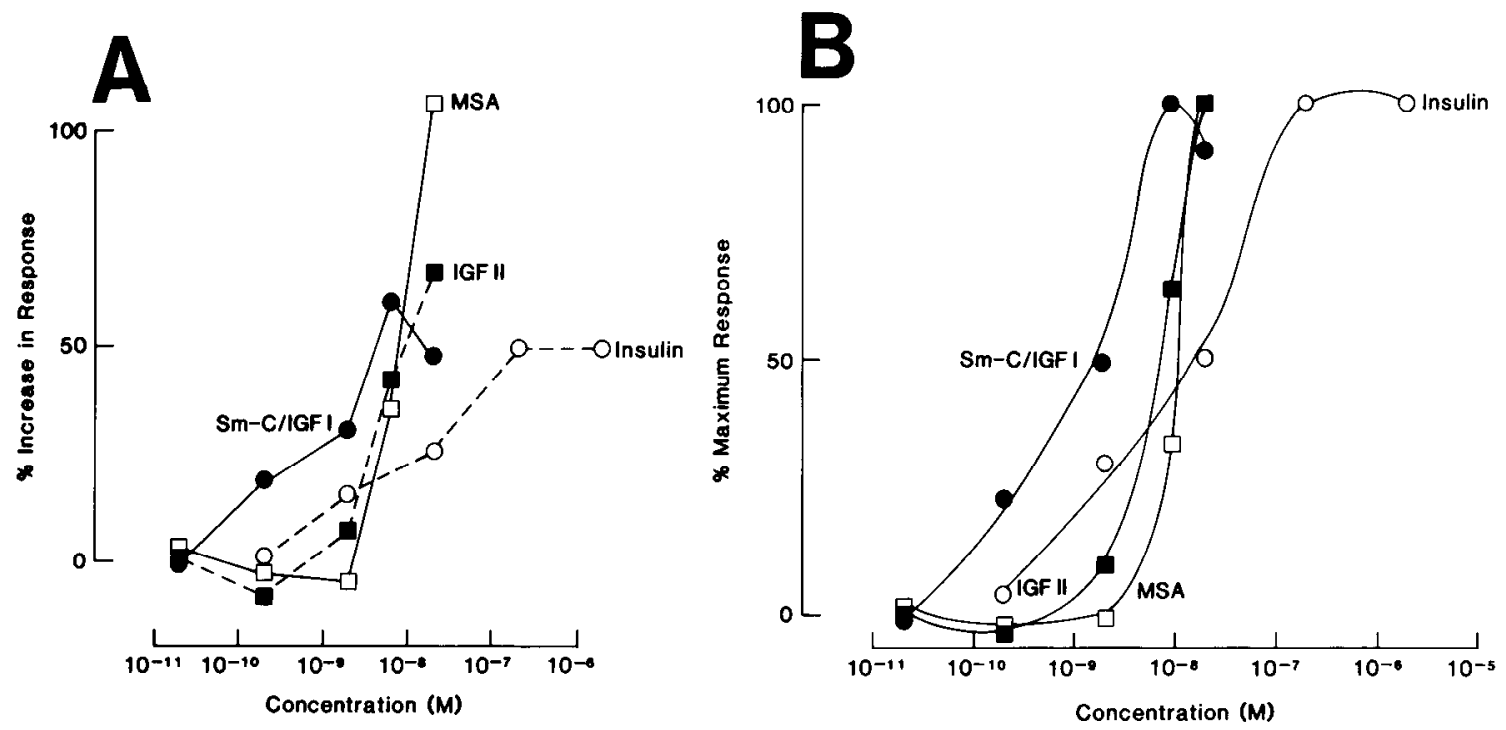

Figure 10. ${ }^{3} \mathrm{H}$-thymidine incorporation of astroglial cells in response to Sm-C/IGF I $(-\odot)$, IGF II $(\square \square)$, MSA ( $\left.\square-\square\right)$, and insulin $(\mathrm{O}-\mathrm{O})$. Each point represents the mean of 6 replicate measurements. ${ }^{3} \mathrm{H}$-thymidine incorporation is expressed as the percentage increase above control $(A)$ and as the percentage of maximum response $(B)$. A duplicate experiment showed almost identical ${ }^{3} \mathrm{H}$-thymidine incorporation responses. Maximum responses with IGF II and MSA were achieved with concentrations of $2 \times 10^{-8} \mathrm{M}$. Half-maximal responses are as follows: Sm-C/IGF I, $0.7 \mathrm{nM}$; IGF II, $6.0 \mathrm{nM}$; MSA, $8.0 \mathrm{nM}$; and insulin, $14 \mathrm{nM}$.

\section{Discussion}

As a first step towards defining the role of Sm/IGFs in neural development, we have identified and characterized Sm/IGF receptors in a pure population of astroglial cells in vitro and presented evidence that these receptors mediate the mitogenic response stimulated by these peptides. Astroglial cells were chosen to study the role of Sm/IGFs in neural development because they are highly proliferative during fetal and neonatal life, suggesting that they may be capable of proliferation in response to potent mitogens such as $\mathrm{Sm} / \mathrm{IGFs}$. Because they can be isolated and cultured as a relatively homogeneous population (McCarthy and de Vellis, 1980), definitive characterization on a single-cell population is possible. Receptors for Sm/IGFs have been previously identified in neural tissues from various brain regions in rats (Lenoir and Honegger, 1983), both fetal and adult (Sara et al., 1982, 1984). Because these studies were performed on membrane fractions prepared from whole tissues or explant cultures, however, the specific neural cells possessing Sm/IGF receptors could not be identified. More recently, McMorris et al. (1986) have shown that oligodendroglial cells cultured from cerebral cortices of rats of similar ages possess receptors for $\mathrm{Sm}$ $\mathrm{C} / \mathrm{IGF}$ I and that these receptors mediate the mitogenic response to $\mathrm{Sm}-\mathrm{C} / \mathrm{IGF}$ I.

Our autoradiographic studies of Sm/IGF binding suggested that astroglial cells possess Sm/IGF surface receptors. When these studies were performed after incubation at 21 or $37^{\circ} \mathrm{C}$ for $3 \mathrm{hr}$, radiolabeled Sm/IGFs appeared to be localized in and around the nucleus, suggesting internalization. The nucleus may therefore be a site of action of these peptides. This finding also suggests that $\mathrm{Sm} / \mathrm{IGFs}$ are internalized and transported to the sites of action, similar to insulin (Carpentier et al., 1981). However, confirmation of such a mechanism awaits further investigation.

Competitive binding and affinity cross-linking studies confirmed the autoradiographic studies and extended our charac- terization of $\mathrm{Sm} / \mathrm{IGF}$ receptors. Astroglial cells possess both type I and type II Sm/IGF receptors, typical of those defined in other cell types (Adams et al., 1983; Kasuga et al., 1981; Massagué and Czech, 1982). The fact that ${ }^{125}$ I-Sm-C/IGF I can bind to both types of receptors was indicated by 2 findings. First, the biphasic competition curve showed that a portion of ${ }^{125} \mathrm{I}-\mathrm{Sm}$ C/IGF I was extremely sensitive to competition by low concentrations of unlabeled Sm-C/IGF I, while higher concentrations of unlabeled Sm-C/IGF I (identical to those required for unlabeled IGF II to compete for ${ }^{125}$ I-Sm-C/IGF I) were necessary to compete for the remaining bound peptide; when these data were analyzed by the Scatchard method, a curvilinear plot was generated, consistent with binding of this peptide to 2 classes of receptors. Second, the affinity cross-linking studies showed ${ }^{125} \mathrm{I}-\mathrm{Sm}-\mathrm{C} / \mathrm{IGF}$ I complexed to protein bands having relative competition and size characteristics of both receptor types. Previously, ${ }^{125} \mathrm{I}-\mathrm{Sm}-\mathrm{C} / \mathrm{IGF}$ I has been shown to bind to both types of $\mathrm{Sm} / \mathrm{IGF}$ receptors in chick embryo fibroblasts (Adams et al., 1983).

Both competitive binding and affinity cross-linking studies indicatc that insulin binds to the typc I Sm/IGF rcceptor with low affinity. ${ }^{125} \mathrm{I}-\mathrm{Sm}-\mathrm{C} / \mathrm{IGF} \mathrm{I}$ labeling of the $M_{r} 130 \mathrm{~K}$ band (under reducing conditions) can be partially displaced by unlabeled insulin at very high concentration, but insulin has no influence on ${ }^{125} \mathrm{I}-\mathrm{Sm}-\mathrm{C} / \mathrm{IGF}$ I binding to the type II Sm/IGF receptor $\left(M_{r} 260 \mathrm{~K}\right.$ under reducing conditions). The latter finding was confirmed in both competitive binding and affinity crosslinking studies using either ${ }^{125}$ I-IGF II or ${ }^{125}$ I-MSA as radioligands. Our findings are therefore consistent with those of other investigators who have described low-affinity binding of insulin to type I Sm/IGF receptor and the absence of binding to the type II receptor (Rechler et al., 1976). When ${ }^{125}$ I-insulin was used in binding studies on astroglial cells, less than $0.5 \%$ was specifically bound. Parallel affinity cross-linking studies were consistent with binding predominantly to the type I Sm/IGF receptor. Because relatively high concentrations of unlabeled 
Sm-C/IGF I were incapable of completely inhibiting ${ }^{125}$ I-insulin, however, we cannot exclude the existence of a small number of insulin receptors on astroglial cells. Recently, Weyhenmeyer et al. (1985) used light- and electron-microscopic immunocytochemistry with a monoclonal antibody against insulin receptor to demonstrate the presence of specific insulin receptors on neural cells in culture. Previously, Razaida et al. (1980) showed that monolayer cultures of fetal rat brain, composed of neuronal and glial cells, possess both high- and low-affinity binding sites for insulin. It was postulated that the mitogenic effect of insulin was mediated by binding to the low-affinity binding sites. Our studies suggest that the low-affinity binding of insulin is likely to be to the type I Sm/IGF receptor. Cross-reactivity with the type I Sm/IGF receptor could therefore explain the requirement of primary and transformed neural cells for high concentrations $(5-10 \mu \mathrm{g} / \mathrm{ml})$ of insulin (Bottenstein, 1984). Support for this hypothesis is provided by the finding that the thymidine incorporation dose response to insulin parallels that of Sm-C/IGF I at higher concentrations.

${ }^{125} \mathrm{I}-\mathrm{IGF}$ II and ${ }^{125} \mathrm{I}-\mathrm{MSA}$ demonstrated almost identical binding characteristics on astroglial cells, both in competitive binding studies and in the affinity cross-linking studies. Both ${ }^{125} \mathrm{I}-$ IGF II and ${ }^{25}$ I-MSA appear to bind exclusively to the type II $\mathrm{Sm} / \mathrm{IGF}$ receptors: (1) Competition studies with each radioligand were essentially identical whether unlabeled IGF II or MSA was used for displacement; likewise, they yielded nearly identical Scatchard plots with similar affinity constants and receptor numbers. (2) Affinity cross-linking studies showed both ${ }^{125}$ I-IGF II and ${ }^{125}$ I-MSA to be associated with protein bands having competition and size characteristics of type II Sm/IGF receptor. These findings are not unusual for cultured cells of rat origin because when affinity cross-linking studies were performed with cultured fibroblasts from neonatal rat meninges and from kidney of normal rats, we could demonstrate only binding of ${ }^{125}$ I-IGF II and ${ }^{125} \mathrm{I}-\mathrm{MSA}$ to the type II Sm/IGF receptor. Similar results have been reported for ${ }^{125}$ I-MSA binding to chick embryo fibroblasts (Adams et al., 1983) and ${ }^{125}$ I-IGF II binding to rat placental membranes (Pilistine et al., 1984). Because IGF II and MSA share $93 \%$ homology, binding to the same receptors was anticipated. In man, however, ${ }^{125}$ I-IGF II also appears to bind the type I receptor of cultured fibroblasts (Massagué and Czech, 1982) and placenta membranes (Casella et al., 1986). The reason for these apparent species differences are not clear.

As demonstrated by our TdR incorporation studies, astroglial cells are stimulated to undergo DNA synthesis in response to $\mathrm{Sm} / \mathrm{IGFs}$ and insulin. We believe that we can relate receptor binding to biologic action with some degree of reliability, because unlike previous reports (Adams et al., 1983; Lenoir and Honegger, 1983), we assessed both binding and thymidine uptake in monolayer cultures under similar conditions. Half-maximal binding displacement and stimulation of thymidine incorporation by each Sm/IGF were on the same order of magnitude, suggesting that the receptors we identified mediate the mitogenic response. Our results do not, however, indicate with certainty whether both or only 1 of the receptors (type I or II) mediates the biologic action. The type I receptor appears to mediate Sm-C/IGF I action, because the half-maximal binding of Sm-C/IGF I to its high-affinity receptor (presumably the type I receptor) and its half-maximal mitogenic response are nearly identical (1.0 and $0.7 \mathrm{~nm}$, respectively). However, affinity-labeling studies showed that ${ }^{125} \mathrm{I}-\mathrm{Sm}-\mathrm{C} / \mathrm{IGF}$ I bound to both type I and type II receptors; therefore, our findings do not exclude the possibility that the mitogenic action Sm-C/IGF I is mediated in part by the type II receptor. With IGF II and MSA, the half-maximal binding displacement (1.0 nM for each) and thymidine incorporation responses $(6.0$ and $8.0 \mathrm{nM}$, respectively) do not correspond precisely, these results suggest that binding to the type I receptor could be responsible for the mitogenic effect of these peptides. On the other hand, Scatchard analysis of both IGF II and MSA binding indicated a single class of receptors, and affinity-labeling studies were consistent with this, showing cross-linking only to type II receptors. Taken together, it is difficult to exclude a biologic role for the type II receptor. Czech et al. (1985) have proposed that the type II receptor does not mediate biologic responses and that type I receptor, rather than the type II receptor, mediates the effects of Sm/IGFs. Other data from different cells are also inconsistent with this hypothesis (Saltman and Gavin, 1985). It may be that the function of the type II receptor differs depending on species or type or developmental stage of the cell studied.

We have identified specific $\mathrm{Sm} / \mathrm{IGF}$ receptors (both type I and type II), and possibly insulin receptors, on astroglial cells cultured from neonatal rats and have shown that they may mediate the mitogenic response of astroglial cells to $\mathrm{Sm} / \mathrm{IGFs}$ and insulin. Our studies indicate that each of the $\mathrm{Sm} / \mathrm{IGFs}$, and possibly insulin, may have important roles in the regulation of brain growth.

\section{References}

Adams, S. O., S. P. Nissley, M. Kasuga, T. P. Foley, and M. M. Rechler (1983) Receptors for insulin-like growth factors and growth effects of multiplication-stimulating activity (rat insulin-like growth factor II) in rat embryo fibroblasts. Endocrinology 112: 971-978.

Bhaumick, B., R. M. Bala, and M. D. Hollenberg (1981) Somatomedin receptor of human placenta: Solubilization, photolabeling, partial purification and comparison with insulin receptor. Proc. Natl. Acad. Sci. USA 78: 4279-4283.

Binoux, M., C. Hossenlopp, C. Lassare, and N. Hardouin (1981) Production of insulin-like growth factors and their carrier by rat pituitary gland and brain cxplants in culturc. FEBS Lett. 124: 178-184.

Birch, N. P., D. L. Christie, and A. G. C. Renwick (1984) Proinsulinlike material in mouse foetal brain cell cultures. FEBS Lett. 168: 299302.

Bottenstein, J. E. (1984) Culture methods for growth of neuronal cell lines in defined media. In Methods for Serum Free Culture of Neuronal and Lymphoid Cells, D. W. Barnes, D. A. Sirbasku, and G. H. Sato, eds., pp. 3-13, Liss, New York.

Carpentier, J.-L., E. Van Obberghen, P. Gorden, and L. Orci (1981) Binding, membrane distribution, internalization and lysosomal association of ${ }^{125}$ I-anti-insulin receptor antibody in IM-9 cultured human lymphocytes: A comparison with ${ }^{125}$ I-insulin. Exp. Cell Res. 134: 81-92.

Casella, S. J., V. K. M. Han, M. E. Svoboda, A. J. D'Ercole, and J. J. Van Wyk (1986) Insulin-like growth factor II binding to the type I somatomedin receptor: Evidence for two high affinity binding sites. J. Biol. Chem. 261: 9268-9273.

Chernausek, S. D., S. Jacobs, and J. J. Van Wyk (1981) Structural similarities between human receptors for somatomedin-C and insulin: Analysis by affinity labeling. Biochemistry 20:7345-7350.

Czech, M. P. (1982) Structural and functional homologies in the receptors for insulin and the insulin-like growth factors. Cell 31: 8-10.

Czech, M. P., R. G. MacDonald, and C. Mottola (1985) Receptors for the insulin-like growth factors. In Somatomedins and Other Peptide Growth Factors, R. L. Hintz and L. E. Underwood, eds., pp. 2027, Report of the Eighty-Ninth Ross Conference on Pediatric Research, Ross Laboratories, Columbus, $\mathrm{OH}$.

Dulak, N. C., and H. E. Temin (1973) Multiplication stimulating activity for chicken embryo fibroblasts from rat liver cell conditioned medium: A family of small peptides. J. Cell Physiol. 81: 161-170. 
Furlanetto, R. W., L. E. Underwood, J. J. Van Wyk, and A. J. D'Ercole (1977) Estimation of somatomedin-C levels in normal and patients with pituitary disease by radioimmunoassay. J. Clin. Invest. 60:648657.

Gorden, P., J.-L. Carpentier, S. Cohen, and L. Orci (1978) Epidermal growth factor: Morphological demonstration of binding, internalization and lysosomal association in human fibroblasts. Proc. Natl. Acad. Sci. USA 75: 5025-5029.

Haselbacher, G., and R. Humbel (1982) Evidence for two species of insulin-like growth factor II (IGF II and "big" IGF II) in human spinal fluid. Endocrinology 110: 1822-1824.

Haselbacher, G., M. E. Schwab, A. Pasi, and R. Humbel (1985) Insulin-like growth factor II (IGF II) in human brain: Regional distribution of IGF II and of higher molecular mass forms. Proc. Natl. Acad. Sci. USA 82: 2153-2157.

Humbel, R. E. (1983) Insulin-like growth factors, somatomedins and multiplication stimulating activity. In Hormonal Proteins and Peptides, Vol. 12, C. H. Li, ed., pp. 57-79, Academic, New York.

Kasuga, M., E. Van Obberghen, S. P. Nissley, and M. M. Rechler (1981) Demonstration of two subtypes of insulin-like growth factor receptors by affinity cross-linking. J. Biol. Chem. 256: 5305-5308.

Klapper, D. C., M. E. Svoboda, and J. J. Van Wyk (1983) Sequence analysis of somatomedin-C: Confirmation of identity with insulinlike growth factor I. Endocrinology 112: 2215-2217.

Laemmli, U. K. (1970) Cleavage of structural proteins during the assembly of the head of bacteriophage T4. Nature 227: 680-682.

Lenoir, D., and P. Honegger (1983) Insulin-like growth factor I (IGF I) stimulates DNA synthesis in fetal rat brain cultures. Dev. Brain Res. 7: 205-213.

Marquardt, H., G. J. Todaro, L. E. Henderson, and S. Oroszlan (1981) Purification and primary structure of a polypeptide with multiplication-stimulating activity (MSA) from rat liver cell cultures: Homology with human insulin-like growth factor II (IGF II). J. Biol. Chem. 256: $6859-6865$.

Massagué, J., and M. P. Czech (1982) The subunit structures of two distinct receptors for insulin-like growth factor I and II and their relationship to the insulin receptor. J. Biol. Chem. 275: 5038-5041.

Massagué, J., B. J. Guillette, and M. P. Czech (1981) Affinity labeling of multiplication stimulating activity receptors in membranes from ral and human tissues. J. Biol. Chem. 256: 2122-2125.

McCarthy, K. D. (1983) An autoradiographic analysis of beta adrenergic receptors on immunocytochemically defined astroglia. J. Pharmacol. Exp. Ther. 226: 282-290.

McCarthy, K. D., and J. de Vellis (1980) Preparation of separate astroglial and oligodendroglial cell cultures from rat cerebral tissues. J. Cell Biol. 85: 890-902.

McMorris, F. A., T. M. Smith, S. DeSalvo, and R. W. Furlanetto (1986) IGF-I/Somatomedin-C: A potent inducer of oligodendrocyte development. Proc. Natl. Acad. Sci. USA 83: 822-826.

Moses, A. C., S. P. Nissley, P. A. Short, M. M. Rechler, and J. M. Podskalny (1980) Purification and characterization of multiplication-stimulating activity. Eur. J. Biochem. 103: 387-400.

Pennock, B. E. (1973) A calculator for finding binding parameters from a Scatchard plot. Anal. Biochem. 56: 306-309.

Pilch, P. F., and M. P. Czech (1979) Interaction of cross-linking agents with the insulin effector system of isolated fat cells. J. Biol. Chem. 254: 3375-3380.

Pilistine, S. J., A. C. Moses, and H. N. Munro (1984) Insulin-like growth factor receptors in rat placental membranes. Endocrinology 115: 1060-1065.

Razaida, M. K., J. W. Yang, and R. E. Fellows (1980) Binding of [ $\left.{ }^{125} I\right]$ insulin to specific receptors and stimulation of nucleotide incorporation in cells cultured from rat brain. Brain Res. 200: 389-400.

Rechler, M. M., J. M. Podskalny, and S. P. Nissley (1976) Interaction of multiplication-stimulating activity with chick embryo fibroblasts demonstrates a growth receptor. Nature 259: 134-136.

Rinderknecht, E., and R. E. Humbel (1978) Primary structure of human insulin-like growth factor II. FEBS Lett. 89: 283-286.

Rosenthal, H. E. (1967) Graphic method for the determination and presentation of binding parameters in a complex system. Anal. Biochem. 20:525-532.

Rubin, J. S., I. Mariz, J. W. Jacobs, W. H. Daughaday, and R. A. Bradshaw (1982) Isolation and partial sequence analysis of rat basic somatomedin. Endocrinology 110: 734-740.

Russell, W. E., I. I. Van Wyk, and W. J. Pledger (1984) Inhibition of the mitogenic effects of plasma by a monoclonal antibody to somatomedin-C. Proc. Natl. Acad. Sci. USA 81: 2389-2392.

Saltman, R. J., and J. R. Gavin III (1985) Demonstration of direct biologic responses to insulin-like growth factor II by cultured $\mathrm{BC}_{3} \mathrm{H}_{1}$ muscle cells. Endocrine Society Program and Abstracts, 187.

Sara, V. R., K. Hall, C. H. Rodeck, and L. Wetterberg (1981) Human embryonic somatomedin. Proc. Natl. Acad. Sci. USA 78: 3175-3179.

Sara, V. R., K. Hall, H. Von Holtz, R. Humbel, B. Sjogren, and L. Wetterberg (1982) Evidence for the presence of specific receptors for insulin-like growth factors 1 (IGF-I) and (IGF-II) and insulin throughout the adult human brain. Neurosci. Lett. 34: 39-44.

Sara, V. R., K. Hall, H. Von Holtz, M. Misaki, L. Pryklund, N. Christensen, and L. Wetterberg (1983) Ontogenesis of somatomedin and insulin receptors in the human fetus. J. Clin. Invest. 71: 1084-1094.

Scatchard, D. G. (1949) The attractions of proteins for small molecules and ions. Ann. NY Acad. Sci. 51: 660-675.

Schoenle, E. J., G. K. Haselbacher, S. Gammeltoft, R. E. Humbel, and A. Prader (1985) Elevated concentration of IGF II in brain tissue in a case of megaencephaly: Postulated role of IGF II in CNS growth. Endocrinology 116: 193 .

Svoboda, M. E., and J. J. Van Wyk (1985) Purification of somatomedin-C/insulin-like growth factor I. In Methods in Enzymology, L. Birnbaumer and B. O'Malley, eds., pp. 798-816, Academic, New York.

Svoboda, M. E., J. J. Van Wyk, D. G. Klapper, R. E. Fellows, F. E. Grissom, and R. J. Schlueter (1980) Purification of somatomedin-C from human plasma: Chemical and biological properties, partial sequence analysis and relationship to other somatomedins. Biochemistry 19: 790-797.

Towle, A. C., J. M. Lauder, and T. H. Joh (1984) Optimization of tyrosine hydroxylase immunocytochemistry in paraffin sections using pretreatment with proteolytic enzymes. J. Histochem. Cytochem. 32: 766-770.

Trimmer, P. A., T. Evans, M. M. Smith, T. K. Harden, and K. D. McCarthy (1984) Combination of immunocytochemistry and radioligand receptor assay to identify beta adrenergic receptor subtypes on astroglia in vitro. J. Neurosci. 4: 1598-1606.

Underwood, L. E., and A. J. D'Ercole (1984) Insulin and insulin-like growth factors/somatomedins in fetal and neonatal development. In Clin. Endocrinol. Metabol. 13: 69-89.

Van Wyk, J. J. (1984) The somatomedins: Biological actions and physiologic control mechanisms. In Hormonal Proteins and Peptides, Vol. 12, C. H. Li, ed., pp. 81-125, Academic, New York.

Van Wyk, J. J., M. E. Svoboda, and L. E. Underwood (1980) Evidence from radioligand assays that somatomedin-C and insulin-like growth factor I are similar to each other and different from other somatomedins. J. Clin. Endocrinol. Metabol. 50: 206-208.

Westermark, B., and A. Wasteson (1975) The responsc of cultured human normal glial cells to growth factors. In Advances in Metabolic Disorders, Vol. 8, Somatomedins and Some Other Growth Factors, R. Luft and K. Hall, eds., pp. 85-100, Academic, New York.

Weyhenmeyer, J. A., A. M. Reiner, I. Reynolds, and A. Killian (1985) Light and electron microscopic analysis of insulin binding sites on neurons in dissociated brain cell cultures. Brain Res. Bull. 14: 415421.

Wilkins, J. R., and A. J. D'Ercole (1985) Affinity labeled plasma somatomedin-C/insulin-like growth factor I binding proteins: Evidence of growth hormone dependence and subunit structure. J. Clin. Invest. 75: 1350-1358.

Zapf, J., C. H. Schmid, and E. R. Froesch (1984) Biological and immunological properties of insulin-like growth factors (IGF) I and II. In Clinics in Endocrinology and Metabolism, Vol. 13 (No. 1), Tissue Growth Factors, W. H. Daughaday, ed., pp. 3-30, Saunders, London. 